\title{
Periodic Manufacturing Industry Clustering Analysis in Yozgat Using the Location Quotient Method (2006-2016)
}

\author{
Yozgat'in Imalat Sanayi Kümelenmesinin Lokasyon Katsayısı \\ Yöntemiyle Dönemsel Incelenmesi (2006-20 I6)
}

\author{
Barış Ergen,1 (i) Muhammed Özgür Oğuz²
}

1'Department of City and Regional Planning, Erciyes University, Kayseri, Turkey

${ }^{2}$ Department of City and Regional Planning, Bozok University, Yozgat, Turkey

\begin{abstract}
This study is an analysis of manufacturing industry clustering in Yozgat in 5-year periods during the years of 2006 to 2016 using the location quotient method. This method is a readily accessible means of performing a spatial evaluation of statistical data. This research investigated which cities in Yozgat have manufacturing industry clusters, which cities' manufacturing industries merit further investment, compatibility with 2013 regional planning proposals, and tendencies in manufacturing industry clustering over the years. According to the number of employees in Yozgat in 2006, there were only manufacturing industry clusters in the districts of Yerköy and Sorgun. There were manufacturing industry clusters in 6 more regions in 2011. By 2016, the districts of Yerköy, Sorgun, Boğazlıyan, and Çayıralan had manufacturing industry clusters. Another important result is that the proximity of Boğazlıyan and Çayıralan to the city of Kayseri provides them with widespread trickle-down effects. This research was performed using the fourth level of the equivalent to the subregions of nomenclature of units for territorial statistics (NUTS-4), and is one of the first such studies of Yozgat.
\end{abstract}

Keywords: Clustering; Location quotient; Manufacturing Industry; NUTS4 Level; Yozgat.

\section{ÖZ}

Bu çalışma Yozgat'ın imalat sanayi kümelenmesi 2006-20I I-20I6 yıllarında beşer yıllık dönemde Lokasyon Katsayısı yöntemiyle araştırılmasını kapsamaktadır. Lokasyon Katsayısı istatistiki verilerin mekânsal değerlendirilmesini sağlaması ve sonuçlarının çabuk elde edilmesi, hesaplamadaki kolaylığı nedeniyle seçilmiştir. Bu çalışmada Yozgat'ın hangi ilçelerinde imalat sanayi kümelenmesinin görüldügü, gelecekte imalat sanayine yapılacak yatırımların hangi ilçelere yapılabileceği ve 2013 yılında hazırlanan bölge planı önerileri ile yıllar içindeki imalat sanayi kümelenme eğiliminin uyumu araştırılmıştır. Sonuç olarak Yozgat'ta 2006 yılında çalışan sayılarına göre sadece Yerköy ve Sorgun İlçelerinde imalat sanayi kümelenmesi görülürken; 20I I yılında bu iki ilçe ile birlikte toplamda 6 ilçede daha imalat sanayi kümelenmesi olduğu görülmüş; 2016 yılına gelindiğinde Yerköy, Sorgun, Boğazlıyan ve Çayıralan ilçelerinde imalat sanayi kümelenmesi olduğu görülmüştür. Boğazlıyan ve Çayıralan ilçelerinin yayılma etkisi (widespread trickle-down effects) ile Kayseri kentine olan yakınlığın etkisinde olduğu bir başka önemli sonuçtur. İstatistiki Bölge Birimleri sınıflandırmasında üçüncü düzey yerleşmelerin de alt bölgeleri olan ilçeler düzeyinde yapılan bu çalışma Yozgat kenti için ilk ve öncü çalışmalardan birisidir.

Anahtar sözcükler: İmalat sanayi; kümelenme; lokasyon katsayısı; NUTS-4, Yozgat.

Received: II.01.2018 Accepted: 25.05.2018

Available Online Date: 01.08 .2018

Correspondence: Barış Ergen.

e-mail: barisergen67@yahoo.com 


\section{Introduction}

\section{Polarization and Growth}

Perroux (1955) pointed out that growth happens in certain growth points or poles with different intensities, does not happen at the same level everywhere and spreads through the whole of the economy from these growth points or poles (Campbell 1997). To be able to ensure growth through polarization, sectoral and spatial combinations should be designed together (Todd 1974). Chakravorty (2003) notes that industrial growth is concentrated in certain cities. Industrial concentration brings polarization. Industries that are polarized in certain regions also show the effects of an agglomeration economy. Chakravorty (2003) also says that concentration of human, physical and financial resources in a certain region, city or periphery brings with it the kind of polarization Hirschman described. Evangelinides (1975) research on Perroux's approach found that economic growth did not exist in a uniform manner, but rather showed a tendency toward spatial polarization.

Dawkins (2003) and Dericioğlu (1988) emphasized the importance of the growth pole theory developed by Hirschman (1958) and Myrdal (1957). Dawkins (2003) and Dericioğlu (1988) also alleged that economic development would occur with polarization, which would have two important effects: I. widespread trickle-down effects, 2. polarization/backwash effects. Therefore, it is expected that the clusters in the manufacturing industry will also have two possible effects. Together with widespread trickle-down effects, it is expected that a settlement or a region with industrial clusters experiences sprawl towards the peripheral settlements or regions where the transport facilities are strong, or there will be new manufacturing industry investments in peripheral settlements or regions. The polarization effect means the rural populations or the peripheries of the settlements or regions with clustering experience increasing economic weakening.

\section{Clusters and Agglomeration}

Clusters are geographic concentrations of interconnected companies, specialized suppliers, service providers, firms in related industries, and associated institutions (e.g., universities, standards agencies, trade associations) in a particular field that compete but also cooperate (Porter 2000). Harrison (1992) noted that similar economic activities have had the tendency to agglomerate in Europe since the Middle Ages, and Porter (1998) said that clustering did not happen everywhere, but only in certain cities and regions. Kowalski and Marcinkowski (2014), referring to Pascal's research (2005), described clustering as an important factor in ensuring the viability of entrepreneurship. Krugman and Venables (1996) emphasized that industrial firms agglomerate in one specific region because of labor force specialization, and this connection between firms brings about clustering. Finally, this clustering leads to a more competitive economic situation. The approach of growth through polarization is directly related to agglomeration economies because of its tendency to cluster in certain regions. Industries clustering in certain regions are directly related to their local features. The human, physical and financial features of a locality are directly related to industrial clustering there.

Karakayacı and Dinçer (20I2) emphasize that the spatial agglomeration of small firms in regional development refers to local characteristics along with production type and production organization. In general, the characterization of agglomeration economies can be examined in two dimensions, industry and geographical location, and is often discussed in the literature together with concentration and specialization issues (Fracasso and Marzetti 2017). "Marshall concluded in his own work about industrial concentration that geographical agglomeration helps firms to find the labor force that they need easily. Marshall's concepts of industrial concentration and industrial region put an emphasis on external economies through the agglomeration of firms" (Sungur 2015: 319). Malmberg (1996) emphasizes that the spatial agglomeration of economic activities is based on three fundamental empirical observations: I) goods are mostly manufactured in the industrial core, 2) similar or related firms choose sites in specific regions, 3) the first two observations remain and maintain valid over time. Clustering is the mutual existence of similar firms and organizations in a certain region and their relations with each other (Sölveli et al. 2008). Regional economic development is shaped by the problems, needs and potentials of regional conditions (Munandar et al. 2017). Local dynamics in regional economic development are important determinants of spatial characteristics, spatial agglomerations and numerical values such as production and work force. Porter's (1990) and Krugman's (1991) works on industry clusters played an important role as these issues became more and more important in regional science, as Karakayacı (2010) has pointed out.

\section{Measure of Clusters and Agglomeration}

There are several approaches to measuring clustering: the Herfindahl-Hirschman index, locational Gini coefficients, and the Ellison-Glaeser geographical concentration index and location quotients (Sungur 2015). This study uses the location quotient (LQ) approach because the study uses the number of registered workers, and LQ is the most suitable way to measure spatial agglomeration. In industrial clusters, one important approach to spatial-geographical data and statistical data is the location quotient method (LQ). 
LQ is an important indicator for measuring agglomeration and is widely used in regional science, especially due to its simplicity in calculation, low cost and low data requirements (Crawley et al. 2013, Tian 2013, Leigh 1970, Isserman 1977). Guimarães et al. (2009) states that LQ was first described by Florence in 1939 as a quantitative accumulation in terms of the number of employees working in industries in a region. Anderson and Bogart (200I) pointed out that LQ is the sectoral percentage of employment in an employment center divided by the same-sector percentage for the entire metropolitan area.

In research carried out by Chiang (2009), LQ is defined as an effective method of determining agglomeration economies in regional economic development. In the literature, LQ is predominantly used as a geographical indicator in spatial analysis (Cromley and Hanink 2012, Gibson et al. 1991), to determine and compare local characteristics (Moineddin et al. 2003), to determine industrial specialization in a geographical domain or region, clustering and economic agglomeration and to promote regional growth (Tian 2013, Crawley et al. 2013, Henderson 2003, Porter 2000, Glaeser et al. 1992).

This study used LQ to obtain rapid results, link spatial data with statistical data for industrial specialization, clustering and economic agglomeration in regional development.

\section{Problem Statement}

Which NUTS-4 (Nomenclature of Territorial Units for Statistics hereafter NUTS) regions of Yozgat are suitable for industrial investments that will contribute to its socio-economic development? Which NUTS-4 regions have manufacturing industry clustering, and how does it change over the years? Are the targeted manufacturing industry development in the sub-region analysis study and sub-region spatial development scheme of Regional Plan of TR 72 (2013) and real changes in manufacturing industry between 2006 to 2016 compatible with each other?

\section{Material}

Data from the Social Security Institution's study, "The Distribution of Insured People in Yozgat NUTS-4 regions and Sectors (NACE (European Classification of Economic Activities) rev. 2)" for the years 2006, 20II and 2016 were used. The main reason this study used data for three separate five-year periods was evaluate change over time.

\section{Methodology: Location Quotient (LQ)}

In this research, annual k-average calculations were done for each NUTS-4 region since "The Distribution of Insured People in Yozgat NUTS-4 regions and Sectors (NACE rev
2)" data is monthly. After calculating annual average values of the number of employees working in manufacturing, the calculation done with $(\mathrm{E})$ method was used to establish ratios between the number of manufacturing industry employees in the NUTS-4 region of Yozgat (ei)/the total number of employees working in manufacturing industry in Yozgat (Ei) and the total number of employees in NUTS-4 region (e)/the total number of employees in Yozgat $(E)$. The formula used in this research was:

$L Q_{i}=\frac{e_{i} / E_{i}}{e / E}$

If the above ratio results in $L Q_{i}<1$, it means that there is no specialization and clustering in manufacturing industry for the selected NUTS-4 region. If the above ratio results in $L Q_{i}=I$, it means that manufacturing industry in that NUTS-4 region is competitive. If the above ratio results in $L Q_{i}>I$, it means that there is a clustering and specialization in manufacturing in the NUTS-4 region (Munandar et al. 2017, Cromley and Hanink 2012, Karakayacı 2010, Seçkin 2015).

\section{Study Highlights}

Turkish LQ studies conducted at the county level have studied all of Turkey or a county and a province. The investigation of manufacturing industry LQ on the NUTS-4 level in Yozgat is the study of TR 72 Region Sub-Region Research (2014) prepared by the Central Anatolia Development Agency. In this study, the analysis in Yozgat, Sivas and Kayseri are all based on net sales and foreign sales (export) data. What makes this research significant is that it is the first study to use NACE rev. 2 data to consider the number of employees in manufacturing at the NUTS-4 level specific to Yozgat.

Another important issue that distinguishes this research is that it used data for 5-year intervals, thus obtaining comparable data suitable for identifying tendencies.

\section{Yozgat}

Yozgat is located in the Central Anatolia Region and is a NUTS-3 level unit in the classification of Turkish Nomenclature of Territorial Units for Statistics. Kayseri, Sivas and Yozgat constitute the Statistical Regional Unit of Kayseri, and Yozgat are in the TR72 NUTS-2 level region. Yozgat is a NUTS-3 level settlement in the statistical regional unit classification. In this research, the NUTS-4 level is the sub-regions of Yozgat NUTS-3 level region. Yozgat has 14 NUTS-4 level sub-regions: Sorgun, Sarıkaya, Boğazlıyan, Merkez, Yerköy, Yenifakılı, Akdağmadeni, Çandır, Çayıralan, Saraykent, Şefaatli, Aydıncık, Çekerek and Kadışehri. The maps below show the TR72 NUTS-2 Level Statistical Unit Region, the Yozgat NUTS-3 Level unit and the NUTS-4 regions of Yozgat (Figure I) 


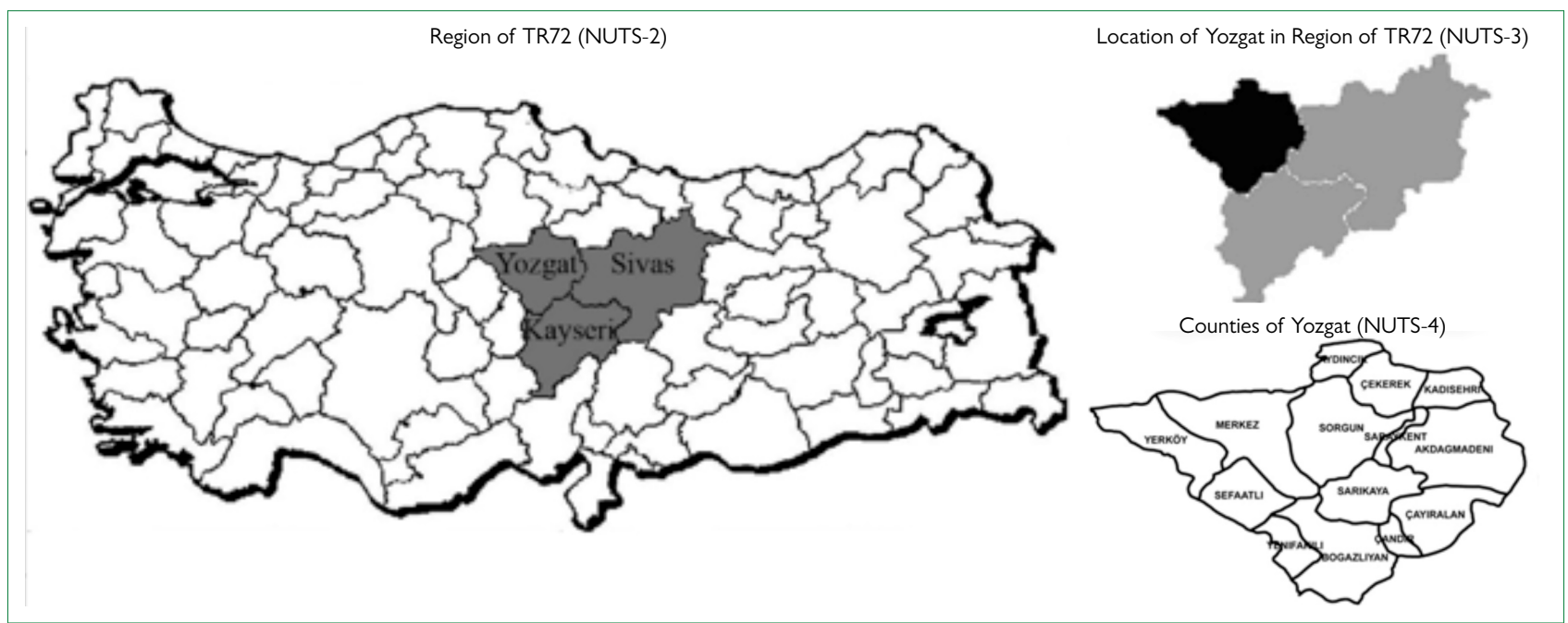

Figure I. The Location of Yozgat.

Yozgat has both railway and motorway (see Figure 2) connections to neighboring cities. The city of Yozgat, which is a NUTS-4 region, has two connections to Kayseri. The first is a motorway through Boğazlıyan NUTS-4 region and is approximately $180 \mathrm{~km}$ long. The second is a motorway that goes through the Sorgun, Sarıkaya and Boğazlıyan NUTS-4 regions and is approximately $200 \mathrm{~km}$ long. Boğazlıyan lies at the intersection of the two roads and is $80 \mathrm{~km}$ from Kayseri. There is also a railway that goes through Ankara, has connections to Kırıkkale and NUTS-4 regions such as Yerköy, Şefaatli, Yenifakılı and arrives in Kayseri. Boğazlıyan is approximately $23 \mathrm{~km}$ from the Yenifakılı train station.

According to the labor force report by the central office of the Yozgat Work and Labor Institution (2013) on sectoral distribution in Kayseri, the total number of employed and registered workers was 368,000. Of them, 135,000 were employed in the industrial sector and accounted for $36.7 \%$ of total employment. According to Turkish Statistical Institute Kayseri has I.376.722 population in 2017 . There can be pos-

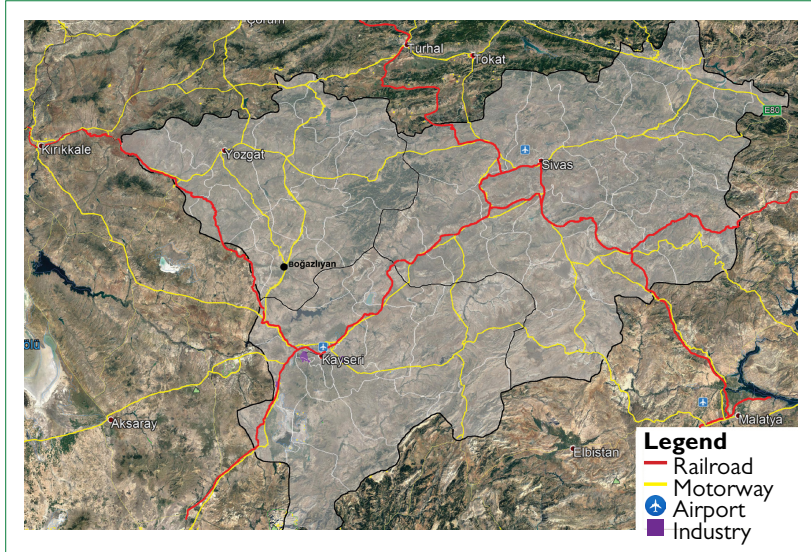

Figure 2. Transportation in TR72. (Source: Google Earth, 2018) sible positive effects in terms of close to market, close to production districts etc...

This study investigated two five-year periods: 2006 to $201 \mathrm{I}$, and $201 \mathrm{I}$ to 2016) using NACE rev. 2 data. To understand the distribution of employment by sector in Yozgat's NUTS-4 regions, three prominent sectors in all of the provinces of the city were investigated and are represented as percentages of overall employment. This study will also contribute to explorations of the changes in manufacturing over the years. Figure 3 shows the distribution of three prominent sectors in Yozgat's NUTS-4 regions. Manufacturing is the prominent sector in the Yerköy, Merkez, Sorgun, Akmağdeni, Sarıkaya, Çayıralan NUTS-4 regions.

According to the 20I I data, there was an important change in manufacturing sector (see Figure 4). Unlike the 2006 data for

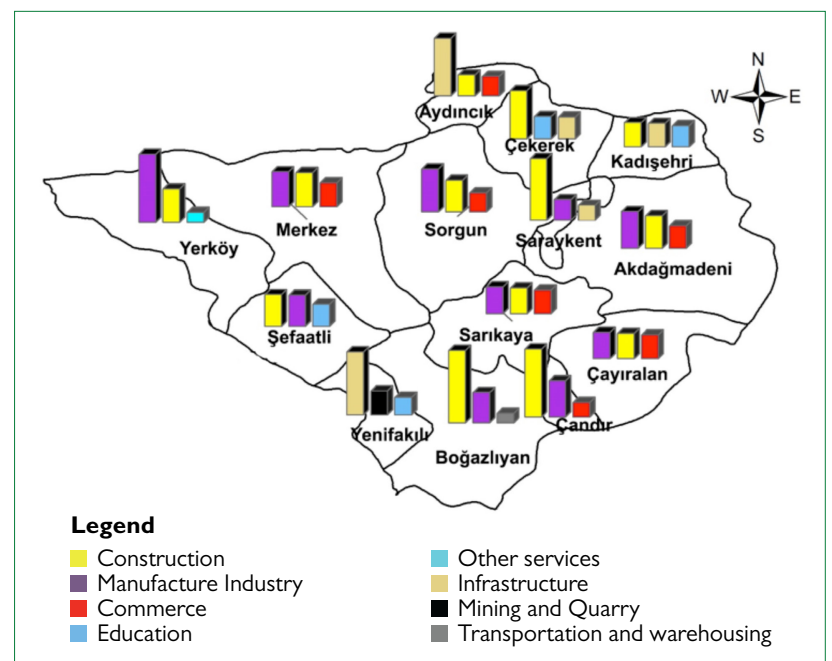

Figure 3. The three prominent sectors of Yozgat's NUTS-4 regions according to number of employees (2006). 
the Yerköy, Merkez, Sorgun, Akmağdeni and Sarıkaya NUTS-4 regions, the most prominent sector was construction. The second most prominent sector in Yerköy, Sorgun and Akmağdeni was manufacturing. The most significant decrease in the manufacturing sector occurred in the Merkez and Sarıkaya NUTS-4 regions where it became the third most prominent sector, and the second most prominent sector was business. According to the 2016 data, the manufacturing sector has showed continuity in NUTS-4 regions in the last ten years. In NUTS-4 regions such as Yerköy, Boğazlıyan and Çayıralan, the most registered workers were employed in the manufacturing sector. In Sorgun, manufacturing was the second prominent sector in 2016, as it was in 2011. However, the number of workers employed in manufacturing was almost as high as the number in construction sector. Figure 5 shows the three sectors that employed the most workers in Yozgat's NUTS-4 regions in 2016.

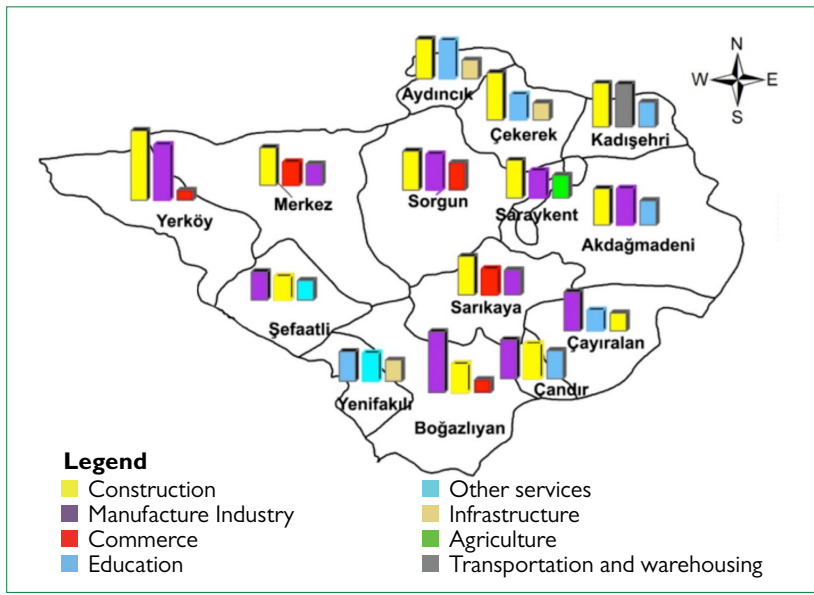

Figure 4. The three prominent sectors of Yozgat's NUTS-4 regions according to number of employees (20I I).

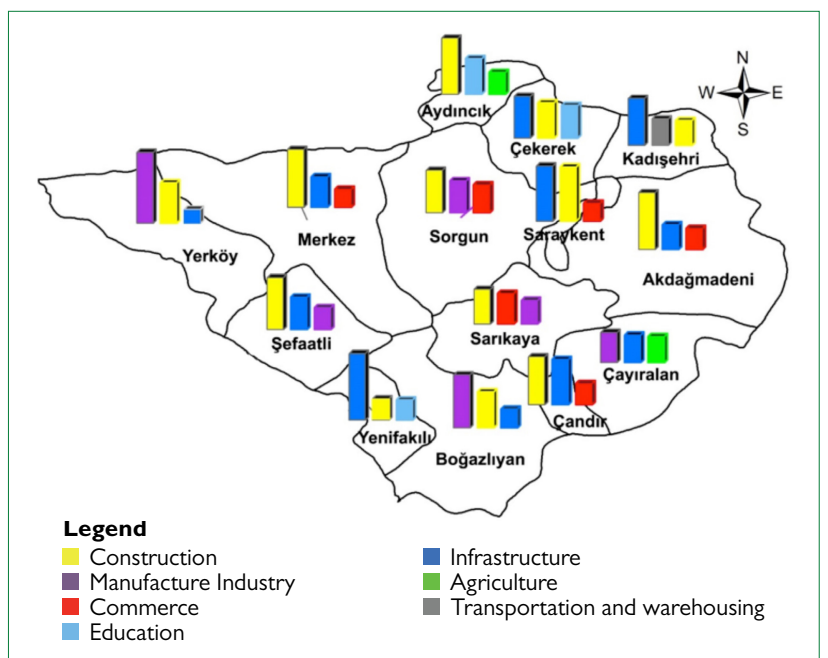

Figure 5. The three prominent sectors of Yozgat's NUTS-4 regions according to number of employees (2016).
Yozgat is a province at NUTS-3 level of the Statistical Regional Units Classification in Turkey. Whether at the provincial or NUTS-4 level, developmental index studies, which measure urban development, provide important information about urban socio-economic structure. Industrial indicators, employment indicators, demographic indicators and urbanization rates, which are essential for socio-economic development studies, are directly related to the manufacturing industry. Manufacturing plays an important role, especially in urbanizing economies. The industry also employs a considerable labor force, which has a significant impact on socio-economic development due to its relationship with other sectors (Lewis 1954, Kern and Schumann 1987, Murphy et al. 1989, Arisoy 2008). In 20II, Yozgat had the 65th highest socio-economic development level out of 81 provinces in Turkey and was 64th in 2003. In 1996, Yozgat was 58th out of 76 provinces. When five provinces were later added, Yozgat was 63rd out of 81 provinces. This shows that Yozgat's socio-economic development level gradually fell in the ranking (Ergen and Ergen 2016). The most recent socioeconomic development level survey conducted at the NUTS-4 region level was done by the State Planning Organization and published in 2004. This research's socio-economic rankings of Yozgat's NUTS-4 regions are shown in Table I.

Source: Socio-economic Development Ranking State Planning Organization 2004

Table I shows that, NUTS-4 regions of Yozgat, only Yerköy and the Center Region (Merkez) have positive socio-economic development indexes for 2004 . The other provinces have negative values. Only the Center Region (Merkez) is in the second development group, and Yerköy, which also has a positive development index, is in the third development group.

Table 2 shows the TR72 Region sub-region study prepared using the data for 2011, 2012, 2013 and published in 2014, indicating the socio-economic development of NUTS-4 regions of Yozgat.

The most important difference between the 2004 and the $201 \mathrm{I}$ development indexes is that Sorgun and Boğazlıyan regions began to take a positive direction.

\section{LQ Analysis for Yozgat Manufacturing Industry in 2006}

In Yerköy and Sorgun, which have a LQ>I value in Table 3 prepared based on the distribution of the Social Security Institution's monthly insured figures for Yozgat's NUTS-4 regions and sectors (NACE rev. 2), manufacturing industry clustering is seen. In other regions, there are no manufacturing industry clusters, not even any competing industry clusters.

Figure 6 and the table above show that manufacturing industry clusters are found only in Yerköy and Sorgun of I4 NUTS 
Table I. Socio-economic Development Index and Ranking for the NUTS-4 Regions of Yozgat in 2004

\begin{tabular}{llll}
\hline County (NUTS-4) & $\begin{array}{c}\text { Development Index } \\
\text { among } 872 \text { County }\end{array}$ & Development Group & Development Index \\
\hline Center & 144 & 2 & 0.75984 \\
Yerköy & 245 & 3 & 0.235 II \\
Çandır & 341 & 3 & -0.03049 \\
Sorgun & 419 & 3 & -0.17494 \\
Boğazlıyan & 445 & 3 & -0.21522 \\
Yenifakılı & 468 & 3 & -0.25045 \\
Çayıralan & 492 & 4 & -0.30647 \\
Şefaatli & 519 & 4 & -0.36524 \\
Sarıkaya & 583 & 4 & -0.47417 \\
Akdağmadeni & 614 & 4 & -0.53296 \\
Saraykent & 725 & 5 & -0.73445 \\
Çekerek & 758 & 6 & -0.81328 \\
Aydıncık & 760 & 6 & -0.81903 \\
Kadısehri & 815 & 6 & -1.10911 \\
\hline Source: & & & \\
\hline
\end{tabular}

Source: Socio-economic Development Ranking State Planning Organization 2004.

regions. One of the other regions, Akdağmadeni, has an LQ value of 0.950 and Çandir has 0.924 , and the Center Region (Merkez) has 0.905. These NUTS-4 regions are closest to the competitive level.

Table 2. Socio-economic Development Index for the NUTS-4 Regions of Yozgat in 20II

\begin{tabular}{lc}
\hline County (NUTS-4) & Development Index \\
\hline Center & 1.325449833 \\
Yerköy & 0.920832209 \\
Sorgun & 0.352672154 \\
Boğazlıyan & 0.108710039 \\
Akdağmadeni & -0.00189693 \\
Sarıkaya & -0.056624364 \\
Şefaatli & -0.135974798 \\
Çayıralan & -0.27917 \\
Yenifakılı & -0.40159 \\
Çandır & -0.43428 \\
Çekerek & -0.47942 \\
Saraykent & -0.61303 \\
Kadışehri & -0.7342 \\
Aydıncık & -0.94669 \\
\hline
\end{tabular}

Source: TR 72 Region Sub-Region Research Central Anatolia Development Agency 2014 .
LQ Analysis of Yozgat's Manufacturing Industry for 2011

Table 4 shows the annual average results of the distribution of the Social Security Institution's monthly insured figures for Yozgat's NUTS-4 Regions and sectors (NACE rev. 2) for 20II. The LQ results are <I for Yerköy, Boğazlıyan, Çandır, Çayıralan and Sorgun. In Sorgun is close to the value of $\mathrm{I}$, a value slightly higher than its competitiveness value.

Figure 7 and Table 4 show that Boğazlıyan, Çandır, Çayıralan, Akdağmadeni joined Yerköy and Sorgun as NUTS-4 Regions with manufacturing industry clustering in 201 I. Especially Boğazlıyan, Çandır and Çayıralan Provinces attracted attention by being close to Kayseri, which has considerable industrial facilities. Boğazlıyan, Çandır and Çayıralan regions are approximately 80 kilometers from Kayseri. Table 4 shows that Akdağmadeni is closest to the competitive value.

\section{LQ Analysis Of Yozgat for 2016 by Means of Manufacturing Industry}

Table 5 shows the annual average results of the distribution of the Social Security Institution's monthly insured figures for Yozgat's NUTS-4 Regions and sectors (NACE rev. 2) for 2016. It shows a decrease in the clustering values compared to 201I. In 2016, Yerköy, Sorgun, Boğazlıyan and Çayıralan had LQ values greater than I. 
Table 3. The Number of Employees Working in the Manufacturing Industry in Yozgat NUTS-4 regions for 2006 and LQ

\begin{tabular}{lccc}
\hline & $\begin{array}{c}\text { Total Employment } \\
\text { (Average) }\end{array}$ & $\begin{array}{c}\text { Total Manufacturing } \\
\text { Industry Employment (Average) }\end{array}$ \\
\hline Akdağmadeni & $1,331.1$ & 310.1 & 0.950 \\
Aydıncık & 210.0 & 2.6 & 0.050 \\
Boğazlıyan & $3,260.0$ & 624.8 & 0.781 \\
Çandır & 183.2 & 41.5 & 0.924 \\
Çayıralan & 449.9 & 75.1 & 0.680 \\
Çekerek & 722.5 & 71.1 & 0.401 \\
Kadışehri & 213.8 & 13.7 & 0.261 \\
Center & $7,695.7$ & $1,708.1$ & 0.905 \\
Saraykent & 244.7 & 32.4 & 0.539 \\
Sarıkaya & $1,033.0$ & 175.9 & 0.694 \\
Şefaatli & 558.5 & 111.3 & 0.813 \\
Sorgun & $4,052.1$ & $1,105.9$ & 1.113 \\
Yenifakılı & 170.0 & 8.3 & 0.198 \\
Yerköy & $3,482.6$ & $1,509.6$ & 1.767 \\
Total & $23,607.1$ & $5,790.3$ & \\
\hline & & & \\
\hline
\end{tabular}

Table 4. The Number of Employees Working in the Manufacturing Industry in Yozgat NUTS-4 Regions for $201 \mathrm{I}$ and LQ

\begin{tabular}{lccc}
\hline & Total Employment (Average) & $\begin{array}{c}\text { Total Manufacturing Industry } \\
\text { Employment (Average) }\end{array}$ & LQ \\
\hline Akdağmadeni & $2,774.9$ & 590.1 & 1.031 \\
Aydıncık & 384.4 & 10.9 & 0.138 \\
Boğazlıyan & $3,083.6$ & $1,095.1$ & 1.722 \\
Çandır & 237.0 & 54.3 & 1.110 \\
Çayıralan & 691.6 & 157.8 & 1.106 \\
Çekerek & $1,104.3$ & 103.9 & 0.456 \\
Kadısehri & 544.1 & 29.5 & 0.263 \\
Center & $11,228.4$ & $1,382.1$ & 0.597 \\
Saraykent & 353.4 & 55.5 & 0.761 \\
Sarıkaya & $1,509.5$ & 217.8 & 0.700 \\
Şefaatli & 767.9 & 127.0 & 0.802 \\
Sorgun & $6,349.5$ & $1,330.0$ & 1.016 \\
Yenifakılı & 257.9 & 29.0 & 0.545 \\
Yerköy & $7,370.4$ & $2,378.1$ & 1.564 \\
Total & $36,657.1$ & $7,561.0$ & \\
\hline & & & \\
\end{tabular}

Figure 8 and Table 5 show that the tendency continues in Sorgun and Yerköy, where manufacturing industry clustering was seen in 2006. Boğazlıyan and Çayıralan continued the tendency of manufacturing industry clustering as they did in $20 \mathrm{II}$. The value of clustering in the manufacturing sector of
Boğazlıyan increased, but Çayıralan's cluster ratio was stable compared to $201 \mathrm{I}$ values.

The alteration of clustering in manufacturing industry in Yozgat's NUTS-4 Regions in five years period from 2006 to 2016 
Table 5. The Number of Employees Working in the Manufacturing Industry in Yozgat NUTS-4 Regions for 2016 and LQ

\begin{tabular}{lccc}
\hline & Total Employment (Average) & $\begin{array}{c}\text { Total Manufacturing } \\
\text { Industry Employment (Average) }\end{array}$ & LQ \\
\hline Akdağmadeni & & 285.8 & 0.595 \\
Aydıncık & $2,917.5$ & 17.0 & 0.196 \\
Boğazlıyan & 528.2 & $1,152.4$ & 1.801 \\
Çandır & $3,889.7$ & 22.9 & 0.524 \\
Çayıralan & 265.7 & 111.8 & 1.014 \\
Çekerek & 670.2 & 75.0 & 0.378 \\
Kadısehri & 1205.8 & 21.6 & 0.198 \\
Center & 664.6 & $1,218.0$ & 0.46 \\
Saraykent & $16,109.2$ & 42.7 & 0.496 \\
Sarıkaya & 522.4 & 235.5 & 0.799 \\
Şefaatli & $1,790.7$ & 124.8 & 0.732 \\
Sorgun & $1,035.4$ & $1,396.3$ & 1.077 \\
Yenifakılı & $7,881.4$ & 38.1 & 0.625 \\
Yerköy & 370.5 & $2,550.4$ & 2.396 \\
Total & $6,470.9$ & $7,292.3$ & \\
\hline & $44,322.1$ & & \\
\hline
\end{tabular}

can be viewed at Figure 9. According to Figure 9 Yerköy and Boğazlıyan NUTS-4 Regions are the most remarkable counties in Yozgat Province.

\section{Discussion and Conclusion}

As mentioned in the introduction, regional development through polarization has positive effects on competitiveness, entrepreneurship, collaboration between firms, interaction and finding appropriate labor force. Clustering in the manufacturing sector does not occur everywhere. It occurs in specific regions. Determining regions with such potential is an important step in regional development. Ensuring regional development through polarization can play an important role in regional planning studies.

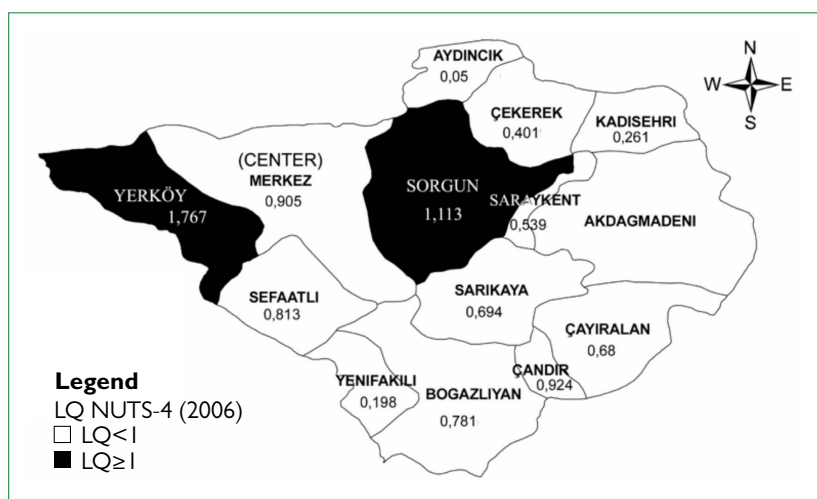

Figure 6. Manufacture Industry LQ Map of Yozgat's NUTS-4 Regions (2006).
This study of clustering in manufacturing in Yozgat's NUTS-4 regions investigated which NUTS-4 regions are more suitable for investment in manufacturing sector to ensure socio-economic development. To do so, the NUTS-4 regions of Yozgat's manufacturing sector that showed continuity between 2006 and 2016 should be determined. This approach also solves this study's second issue: monitoring the change in clustering in the manufacturing sector over time. The fact that a sector becomes prominent and sustains its continuity over time means that sector will show clustering, which will eventually lead to polarization.

I, 2 - The 5-year interval manufacturing industry clustering results for Yozgat between 2006-2016 indicate that only

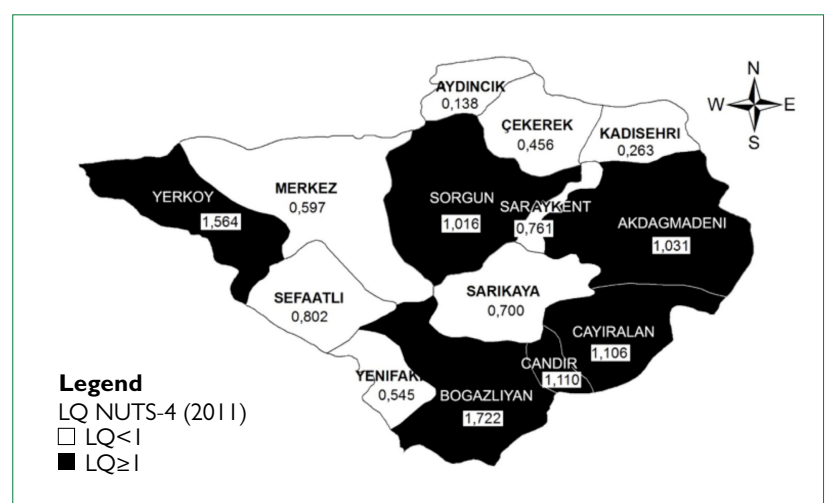

Figure 7. Manufacture Industry LQ Map of Yozgat's NUTS-4 Regions (20II). 
Yerköy and Sorgun had manufacturing industry clustering in 2006 and before by number of employees. In 201 I, some regions' competitive potential, particularly those close to Kayseri, rose. The exceptional region in terms of proximity to Kayseri in 201 I was Akdağmadeni. The 2016 data gives information about the future of manufacturing industry clusters in the regions of Yozgat. In addition to Yerköy and Sorgun, which already had manufacturing industry clusters, manufacturing industry clustering is growing in some other regions due to proximity to Kayseri, especially in Boğazlıyan. Even if Çayıralan is 80 kilometers from Kayseri, the fact that Boğazlıyan's transportation facilities are good made it rise slightly above the competitive value. Yerköy's manufacturing industry clustering is becoming increasingly polarized. Yerköy's location on the Ankara-Yozgat road, its proximity to Ankara, its current railway transportation, its location on the (yet to be completed) high-speed railway and its two organized industrial zones are the main causes of clustering in its manufacturing industry.

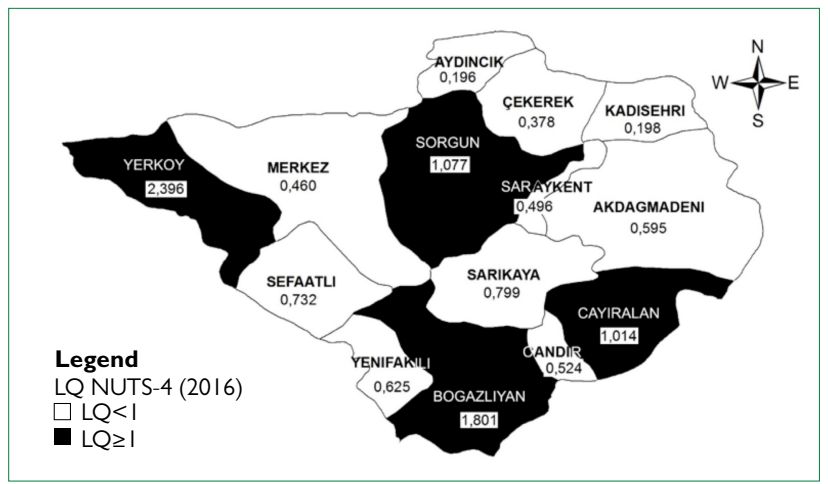

Figure 8. MManufacture Industry LQ Map of Yozgat's NUTS-4 Regions (2016).
The socio-economic development index and ranking survey conducted at the NUTS-4 level was done by the State Planning Organization and published in 2004 (see Table I). It shows a significant relationship between the $L Q$ values for 2006. The results ranked the Center Region (Merkez), Yerköy, Çandır, Sorgun and Boğazlıyan in order of socio-economic development index in 2004, and Yerköy, Sorgun, Akdağmadeni, Çandır and the Center Region (Merkez) in 2006. The LQ rankings were Boğazlıyan, Yerköy, Çandır, Çayıralan, Akdağmadeni and Sorgun in 20I I, and the Center Region (Merkez), Yerköy, Sorgun, Boğazlıyan and Akdağmadeni according to 2011-2012-2013 values of socio-economic development indexes prepared by the Central Anatolia Development Agency in 2014. The socio-economic development index indicates that socio-economic variables other than the manufacturing industry are not certain to yield the same result due to the input effect, but this can be interpreted as a positive effect of the socio-economic structure of the manufacturing clusters on the provinces.

Figures 3, 4 and 5 show the change in all of Yozgat's NUTS-4 regions. Employment in the manufacturing sector decreases over time in Merkez, Sorgun, Akmağdeni, Sarıkaya NUTS-4 regions. It is possible to explain positive effects on Boğazlıyan and Çayıralan due to their proximity to the manufacturing industry of Kayseri with the widespread trickle-down effects approach. Over the years, the clustering rate of the manufacturing industry is gradually decreasing in the Center Region (Merkez). The presence of the university in the Center Region (Merkez) is mainly due to university-based investments. Especially investments in construction, commerce, administrative services reduce manufacturing industry clustering.

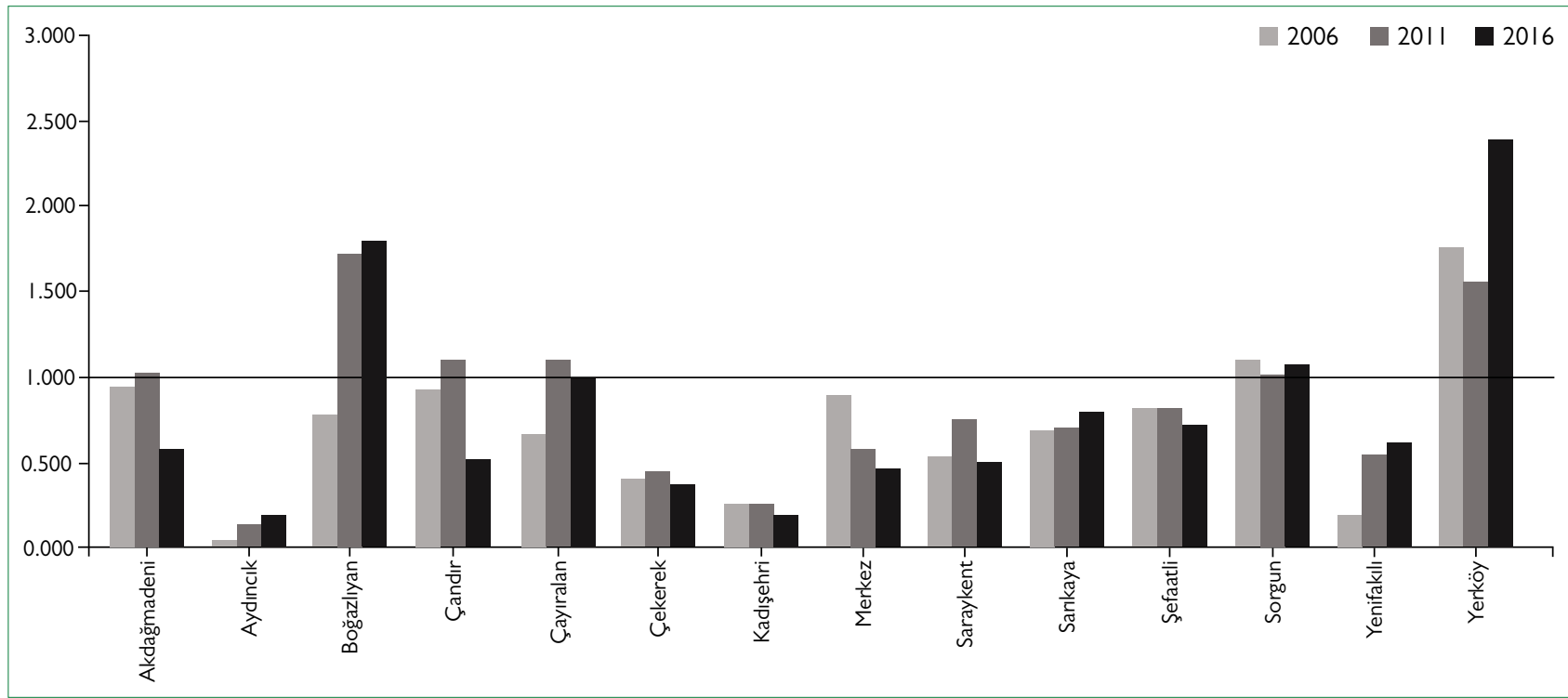

Figure 9. Manufacture Industry LQ Alteration of Yozgat's NUTS-4 Regions (2006-20I6). 
3- This study's third issue was to compare its findings to the decisions made in the 2013 regional plan. Investing in an area where there is clustering in the manufacturing sector is more likely to succeed because of the labor force, financial resources and local features. Clustering in manufacturing developed continuously and consistently in Yerköy, Sorgun, Boğazlıyan and Çayıralan from 2006 to 2016. The 2013 regional plan for the TR72 NUTS-2 region was prepared based on data from 2010 and earlier. This study will make it possible to investigate changes in the 2013 plan decisions and how compatible those decisions were with development in these regions. Figure 2 shows that in 2006, prominent sector in the Merkez NUTS-4 region was manufacturing. For this reason, the regional plan included a decision to invest in manufacturing in the Merkez NUTS-4 region. The Regional Plan of TR 72's sub-sector prepared in 2013 and the number-2 sub-regional spatial scheme studies foresees manufacturing industry investments in Yerköy and the Center Region (Merkez), and it proposes development in industry in these two regions. However, employment in manufacturing fell in the Merkez NUTS-4 region from 2011 to 2016. The Center Region (Merkez) does not feature clustering in manufacturing industry. The result of the study, which is not proposed in the TR 72 Regional Plan (2013), is that manufacturing industry is gradually clustering in Boğazlıyan. Therefore, Boğazlıyan's manufacturing industry needs support.

Our study focused on the concentration of manufacturing industry at the NUTS-4 level. It used the LQ method with data for the distribution of employees by sector and identified industrial clusters in Yerköy, Sorgun, Boğazlıyan and Çayıralan in 2016. According to the same employment data, the Yerköy, Sorgun, Boğazlıyan and Çayıralan NUTS-4 regions seem to be most appropriate for investments in manufacturing. This study will provide significant data for future plans for the province of Yozgat and/or the TR 72 Region.

\section{REFERENCES}

Anderson, N.B., and Bogart, W., (2001). The Structure of Sprawl: Identifying and Characterizing Employment Centers in Polycentric Metropolitan Areas. The American Journal of Economics and Sociology, 60(1), 147-169.

Arısoy, I., (2008). Türkiyéde Sanayi Sektörü - Iktisadi Büyüme Ilişkisinin Kaldor Hipotezi Çerçevesinde Test Edilmesi, Discussion Paper, Turkish Economic Association, 1, 1-31.

Campbell, J., (1974). A note on growth poles. Growth and Change, 5(2), 43-45.

Chakravorty, S., (2003). Industrial location in post-reform India: patterns of inter-regional divergence and intra-regional convergence, The Journal of Development Studies, 40(2), 120-152.

Chiang, S., (2009). Location Quotient and Trade. Ann. Reg. Sci., 43, 399-414.

Crawley, A., Beynon, M., and Munday, M., (2013). Making Location Quotients More Relevant as a Policy Aid in Regional Spatial Analysis. Urban Studies, 50(9), 1854-1869.

Cromley, R.G., and Hanink, D.M., (2012). Focal Location Quotients: Specification and Applications. Geographical Analysis, 44(4), 398-410.

Dawkins, C.J., (2003). Regional Development Theory: Conceptual Foundations, Classic Works, and Recent Developments. Journal of Planning Literature., 18(2), 131-172.

Dericioğlu, K.T., (1988). Az Gelişmiş Ülkelerde Kırsal Alanlara Yönelik Güncel Bölge Planlama Yaklaşımları [Current Regional Planning Approaches for Rural Areas of Developing Countries], METU Journal of Architecture, vol. 8, no. 1, pp. 11-22.

Ergen, B., and Ergen, Z., (2016). Unifying Two Regional Planning Methodologies in an Analysis of the Rural and Agricultural Development Potential of the Province of Yozgat, Turkey Romanian Review of Regional Studies, 12(1), 51-64.

Evangelinides, M., (1975). Regional development- core-periphery relations: the Greek case. The Greek Review of Social Research, 24, 320-255.

Florence, P.S., (1939). Report on the Location of Industry. Political and Economic Planning, London, U.K.

Fracasso, A., and Marzetti, G.V., (2017). Estimating dynamic localization economies: the inadvertent success of the specialization index and the location quotient. Regional Studies, 1-14.

Gibson, J., Miller, M. and Wright, G. (1991). Location quotient: a basic tool for economic development analysis. Economic Development Review, $9(2), 65-68$.

Glaeser, E. L., Kallal, H. D., Scheinkman, J. A., \& Shleifer, A. (1992). Growth in cities. Journal of Political Economy, 100(6), 1126-1152.

Guimarães, P., Figueiredo, O., and Woodward, D., (2009). Dartboard tests for the location quotient. Regional Science and Urban Economics, 39, 360-364.

Harrison, B., (1992). Industrial Districts: Old Wine in New Bottles? Regional Studies (26)5, 469-483.

Henderson, J.V., (2003). Marshall's scale economies. Journal of Urban Economics, 53(1), 1-28.

Hirschman, A. O., (1958). The Strategy of Economic Development, Yale University Press, New Haven.

Isserman, A.M., (1977). The Location Quotient Approach to Estimating Regional Economic Impacts. Journal of the American Institute of Planners, 43(1), 33-41.

Karakayacı, Ö., (2010). Ekonomik Büyüme ve Girişimcilik Aktivitelerinde Kümeleşmenin Rolü: Bursa ve Konya Sanayi Kümeleri Örneğinde Karşılaştırmalı Bir Araştırma.[ Role of Clustering in Economic Growth and Entrepreneurship Activity: The Comparative Study in Case of Bursa and Konya Industrial Clusters] Megaron, 5(3), 149-159.

Karakayacı, Ö., and Dinçer, İ., (2012). Sanayi Kümelerinde Firma Özellikleri, Bilgi Ağlari ve Yenilikçilik. [Firm Characteristics, Knowledge Networks and Innovativeness In Industrial Clusters] Sigma, 4, 22-36.

Kern, H., and Schumann, M., (1987). Limits of the Division of Labour New Production and Employment Concepts in West German Industry. Economic and Industrial Democracy, 8, 151-170. 
Kowalski A.M., and Marcinkowski A., (2014). Clusters versus Cluster Initiatives with Focus on the ICT Sector in Poland. European Planning Studies, 22(1), 20-45.

Krugman, P., (1991). Geography and Trade, Cambridge, MIT Press.

Krugman, P., ve Venables A.J., (1996). Integration, specialization, and adjustment. European Economic Review, 40, 959-967.

Labor Force Report by the Central office of the Yozgat Work and Labor Institution (2013). http://www.iskur.gov.tr/tr-tr/kurumsalbilgi/raporlar. aspx\#dltop (access date 24th of April 2018).

Leigh, L., (1970). The Use of Location Quotients in Urban Economic Base Studies. Land Economics, 46(2), 202-205.

Lewis, W.A., (1954). Economic Development with Unlimited Supplies of Labour. The Manchester School, 22(2), 139-191.

Malmberg, A., (1996). Industrial geography: agglomeration and local milieu. Progress in Human Geography, 20(3), 392-403.

Moineddin, R., Beyene, J., and Boyle, E., (2003). On the Location Quotient Confidence Interval. Geographical Analysis, 35(3), 249-256.

Munandar T.B., Azhari, Musdholifah A., and Arsyad, L., (2017). Modified Agglomerative Clustering with Location Quotient for Identification of Regional Potential Sector. Journal of Theoretical and Applied Information Technology, 95(5), 1191-1199.

Murphy, K.M., Shleifer, A., and Vishny, R.W., (1989). Industrialization and the Big Push. Journal of Political Economy, 97(5), 1003-1026.

Myrdal, G., (1957). Economic Theory and Underdeveloped Regions, Gerald Duckworth \& Co. Ltd London.

Pascal, V.J., (2005). Clusters and entrepreneurial intensity: The influence of economic clusters on entrepreneurial activity. Journal of Research in Marketing and Entrepreneurship, 7(1), 5-27.

Perroux, F., (1955). A note on the notion of growth pole [Notes sur la notion des pöles de croissance]. Applied Economy [Economie Appliqude], 1(2), 307-320. As translated in Regional Economics, ed. David L. McKee, Robert D. Dean, and William H. Leahy (New York: Free Press, 1970). P. 94.

Porter, M.E., (1990). The Competitive Advantage of National, New York, The Free Press.

Porter, M.E., (1998). Location, Clusters, and the "New" Microeconomics of Competition. Business Economics, 33(1), 7-13.

Porter, M.E., (2000). Location, Competition, and Economic Development: Local Clusters in a Global Economy. Economic Development Quarterly, 14(1), 15-34.

Seçkin, E., (2015). Perakende Sektöründeki Yapısal Dönüşümün Bursa'daki Üretim Piyasası ile Tüketim Piyasasına Yansıması. [The Impact of Structural Transformation in Retail Sector on the Producer and Consumer Market in Bursa] Megaron, 10(1), 70-79.

Socio-economic Development Ranking (2004). State Planning Organization (http://www.kalkinma.gov.tr/Lists/Yaynlar/Attachments/299/ilce.pdf access date 13th November 2017)

Sölvell, Ö., Ketels, C., and Lindqvist, G., (2008). Industrial specialization and regional clusters in the ten new EU member states. Competitiveness Review: An International Business Journal, 18(1-2), 104-130.

Sungur, O., (2015). TR61 (Antalya, Isparta, Burdur) Bölgesinde Sektörel Yoğunlaşmanın ve Yoğunlaşma Dinamiklerinin Analizi. Yönetim ve Ekonomi Araştırmaları Dergisi, 13(3), 316-341.

Tian, Z., (2013). Measuring Agglomeration Using the Standardized Location Quotient with a Bootstrap Method. The Journal of Regional Analysis and Policy, 43(2), 186-197.

Todd, D., (1974). An appraisal of the development pole concept in regional analysis. Environment and Planning A, (6), 291-306.

TR 72 Region Sub-Region Research (2014). Central Anatolia Development Agency, (http://www.oran.org.tr/images/dosyalar/20170915132804_0. pdf access date 13th November 2017)

TR 72 Regional Plan (2013). Central Anatolia Development Agency (http:// www.oran.org.tr/images/dosyalar/111.pdf access date 24th of April 2018). 